\title{
Evaluation Quality of Life of Patients Wearing Implant- Supported Overdentures and Conventional Complete Dentures
}

\author{
Büyükerkmen EB ${ }^{1}$ and Öncü $E^{2 *}$ \\ ${ }^{1}$ Department of Prosthodontics, Necmettin Erbakan \\ University, Turkey \\ ${ }^{2}$ Department of Periodontolgy, Necmettin Erbakan \\ University, Turkey \\ *Corresponding author: Elif Öncü, Department of \\ Periodontolgy, Necmettin Erbakan University, Konya, \\ Turkey
}

Received: March 15, 2017; Accepted: May 03, 2017; Published: May 18, 2017

\begin{abstract}
Objectives: The study uses OHIP-EDENT questionnaire and aims to assess and compare the denture satisfaction of patients with classical complete denture and implant supported overdenture.

Materials and Methods: In the study, 40 individuals applied for maxilla and submaxilla complete denture to the Faculty of Dentistry, Necmettin Erbakan University were included. 20 patients with classical maxilla and submaxilla complete denture were identified as control group, whereas 20 patients with classical maxilla complete denture and with two implant supported overdenture bilaterally placed on canine in mandibular region were identified as test group. All subjects completed an OHIP post treatment during the first year. Using an item impact reduction method, a shortened version of the OHIP (called OHIPEDENT) was derived from both datasets. Differences between both groups were evaluated by answers given by the subjects.
\end{abstract}

Results: The patients were asked to complete a total of 28 questions in 3 different categories. Answers of all questions were analyzed according to each category. In test group, problems regarding denture and mastication satisfaction were found significantly lower. No statistically significant difference was observed between groups in the evaluation of aesthetical satisfaction.

Conclusion: After the assessment of all results, overall satisfaction level of test group was found significantly higher than that of control group. It's concluded that overdenture treatment should be considered as an alternative to classical complete denture in mandibular region.

Keywords: Overdenture treatment; Prosthetic rehabilitation; Oral health impact profile

\section{Introduction}

Prosthetic rehabilitation of edentulous jaws includes compelling treatments both for dentists and patients. Thanks to recent developments in implant technologies, conventional prosthetic treatment methods used for tooth loss have undergone remarkable changes [1].

Endosteal implants are frequently implemented as a supporter of fixed or removable denture in the case of loss of one or more teeth when conventional dentures provide inconvenient satisfaction [15]. Today, implant treatments are widely welcomed by the public as a result of lower cost, the increasing number of practitioners and advertisements or commercials. It's reported the idea that implant treatments are for rich people is no more valid and these treatments have become a standardized and preferred method of treatment for a vast majority of public [2-5].

For cases with edentulous jaw, complete denture rehabilitation is conventionally used and the use of such dentures is really difficult. In literature, there are many studies carried out to work out and develop functional efficiency of these dentures [6]. Implant supported dentures, therefore, have been a widely preferred method to simplify the use and to increase functional comfort of dentures [6,7]. However, rehabilitation with complete dentures is still the most commonly preferred prosthetic method even today as it makes patients have dentures in a shorter time at a much lower cost $[8,9]$.

The fact that complete dentures applied on extremely resorbed edentulous crests have inadequate stabilization and that food remains move under the dentures and cause discomfort during nutrition and conversation have made overdentures more desirable and preferable. Less stabilization problems are coincident in complete dentures placed on maxilla, for this reason, overdentures are more widely preferred on submaxilla due to stabilization problems of complete dentures on submaxilla [7].

Normally, while evaluating the success of prosthetic rehabilitations, dentists pay more attention on the health of supporter tissues and general appearance of the denture than they do on patient satisfaction. However, patient satisfaction is of primary importance for the success of a denture $[10,11]$.

In literature, there are many studies evaluating the denture satisfaction of patients that have received complete denture, overdenture or full arc rehabilitation treatments. Various different
Austin J Dent - Volume 4 Issue 4 - 2017

ISSN : 2381-9189 | www.austinpublishing group.com

Öncï et al. @ All rights are reserved
Citation: Büyükerkmen EB and Öncü E. Evaluation Quality of Life of Patients Wearing Implant-Supported Overdentures and Conventional Complete Dentures. Austin J Dent. 2017; 4(4): 1077. 
Table 1: Denture satisfaction evaluation.

\begin{tabular}{|c|c|c|}
\hline Functional Problems & Mastication Capacity Problems & Denture Satisfaction Problems \\
\hline $\begin{array}{l}\text { 1-1. Have you ever had any difficulties due to the denture } \\
\text { while speaking? } 011234\end{array}$ & 2-1. Do you have difficulty while chewing? $\begin{array}{lllll}0 & 1 & 2 & 3 & 4\end{array}$ & $\begin{array}{l}\text { 3-1. How often do you take out your } \\
\text { denture as it hurts? }\end{array}$ \\
\hline $\begin{array}{l}\text { 1-2. Have you ever felt taste differences due to the } \\
\text { denture? } \begin{array}{lllll}1 & 2 & 3 & 4\end{array}\end{array}$ & $\begin{array}{l}\text { 2-2. Do you feel increased saliva in your mouth? } 012 \\
34\end{array}$ & $\begin{array}{l}\text { 3-2. How satisfied are you with your } \\
\text { maxilla denture? }\end{array}$ \\
\hline $\begin{array}{l}\text { 1-3. Have you ever felt pain while using the denture? } 01 \\
234\end{array}$ & $\begin{array}{l}\text { 2-3. Do you take out your denture while eating? } 01123 \\
4\end{array}$ & $\begin{array}{l}\text { 3-3. How satisfied are you with your } \\
\text { submaxilla denture? }\end{array}$ \\
\hline 1-4. Do you feel pain while eating? 01234 & $\begin{array}{l}\text { 2-4. Do you completely trust in your denture while eating? } \\
01234\end{array}$ & $\begin{array}{l}\text { 3-4. To what extent are you satisfied with } \\
\text { your dentures? }\end{array}$ \\
\hline $\begin{array}{l}\text { 1-5. Does your denture move easily while eating? } 012 \\
34\end{array}$ & $\begin{array}{l}\text { 2-5. Do you think that the denture affects your nutrition? } 0 \\
1234\end{array}$ & $\begin{array}{l}\text { 3-5. How satisfied are you with your } \\
\text { denture during function? }\end{array}$ \\
\hline $\begin{array}{l}\text { 1-6. Does your denture move easily while speaking? } 01 \\
234\end{array}$ & $\begin{array}{l}\text { 2-6. Have you ever stopped eating due to the denture? } 0 \\
\begin{array}{lll}12 & 34\end{array}\end{array}$ & \\
\hline 1-7. Do you feel pain while drinking? 0121234 & $\begin{array}{l}\text { 2-7. Do you have difficulty while eating food with hard inner } \\
\text { or outer parts? } \begin{array}{lllll}0 & 1 & 2 & 3 & 4\end{array}\end{array}$ & \\
\hline $\begin{array}{l}\text { 1-8. Have you ever felt that the food goes under the } \\
\text { denture? } \begin{array}{llllll}0 & 1 & 2 & 3 & 4\end{array}\end{array}$ & $\begin{array}{l}\text { 2-8. Do you have difficulty while eating food with soft inner } \\
\text { or outer parts? } \begin{array}{lllll}0 & 1 & 2 & 3 & 4\end{array}\end{array}$ & \\
\hline \multicolumn{3}{|l|}{$\begin{array}{l}\text { 1-9. Do you feel pain when you open your mouth to take } \\
\text { the denture out? } 01234\end{array}$} \\
\hline \multicolumn{3}{|l|}{ 1-10. Do you trust in your denture? $0 \begin{array}{llll}0 & 1 & 3 & 4\end{array}$} \\
\hline \multicolumn{3}{|l|}{$\begin{array}{l}\text { 1-11. Do you hear clattering/clicking while eating or } \\
\text { speaking? } 01234\end{array}$} \\
\hline \multicolumn{3}{|l|}{$\begin{array}{l}\text { 1-12. Do your facial expressions change after you place } \\
\text { your denture? } 011234\end{array}$} \\
\hline $\begin{array}{l}\text { 1-13. Do you bite your cheek or tongue mucosa membrane } \\
\text { often? } 01234\end{array}$ & & \\
\hline
\end{tabular}

Score: 1-4 (1=never, 2=sometimes, 3=generally, 4=always)

Table 2: Statistical result graph.

\begin{tabular}{|c|c|c|c|}
\hline Treatment & TEST $(\mathbf{n}=\mathbf{2 0})$ & CONTROL $(\mathbf{n = 2 0})$ & $\mathbf{p}$-Value \\
\hline Denture Problems & $1.04 \pm 0.21$ & $2.16 \pm 0.52$ & $<0.001$ \\
\hline Mastication Problems & $1.11 \pm 0.19$ & $2.01 \pm 0.45$ & $<0.001$ \\
\hline Overall Satisfaction & $8.28 \pm .24$ & $5.98 \pm .66$ & $<0.001$ \\
\hline Aesthetical Satisfaction & $8.16 \pm 1.97$ & $8.01 \pm 1.83$ & 0.632 \\
\hline
\end{tabular}

indexes were used in these studies to evaluate denture satisfaction. To measure general denture satisfaction, Oral Health Impact Profile (OHIP) questionnaire was designed. The questionnaire is used to evaluate functional, aesthetical and psychological problems and satisfaction of patients with dentures [12].

In order to simplify, limit and minimize the questionnaire for complete dentures, Allen and Locker adapted the original OHIP for edentulous patients and modified a short version as OIHP-EDENT [13].

The study uses OHIP-EDENT questionnaire and aims to assess and compare the denture satisfaction of patients with classical complete denture and implant supported overdenture.

\section{Materials and Methods}

The ethics committee approval of the study was given by the ethics committee of the Faculty of Dentistry, Necmettin Erbakan University and the study complies with Helsinki Declaration. The patients included in the study were informed through verbal dialogues and written forms and asked to fulfill a signed consent form. In the study, 40 individuals applied for maxilla and submaxilla complete denture to the Faculty of Dentistry, Necmettin Erbakan University were included. 20 patients with classical maxilla and submaxilla complete denture were identified as control group, whereas 20 patients with classical maxilla complete denture and with two implant supported overdenture bilaterally placed on canine in mandibular region were identified as test group.
All dentures were made by the same expert (B.B) and all implants were placed by the same periodontology expert (E.Ö). After the first year, all patients were invited to the clinic and asked to fulfill the questionnaire.

In the study, comprehensive satisfaction questionnaire developed by Boerrigter method was used. According to this questionnaire, during the denture satisfaction evaluation, there are three vital factors that need to be taken into account: [14] ( $1^{\text {st }}$ Category). The questions in this category should focus on whether there are complications resulting from the denture and whether the denture itself has problems or causes dissatisfaction problems (Table 1). ( $2^{\text {nd }}$ Category) This category focuses on the evaluation of mastication capacity. The satisfaction of patients while masticating different food items is evaluated (Table 1) ( $3^{\text {rd }}$ Category). Overall denture satisfaction, aesthetical dissatisfaction, physical or psychological sense resulting from the denture is evaluated. In the study, questionnaires prepared in accordance with the given categories were answered by the patients. The evaluation of overall satisfaction questionnaire results was shown on a linear graph prepared depending on Grandmont (1994) [15] method. On a linear visual analogue scale (VAS) showing numbers from 1 (dissatisfied) to 10 (satisfied), the patients were asked to mark the level of their denture satisfaction [15].

\section{Statistical analysis}

IBM SPSS Statistics 22 (IBM SPSS, Turkey) was used for statistical analysis of the findings. Whether the samples show normal distribution or not was evaluated by Kolmgorov-Smirnov test. For the analysis of the differences between questionnaire results, both independent $t$-test and Kruskal-Wallis tests were used.

\section{Results}

The patients were asked to complete a total of 28 questions in 3 different categories. Answers of all questions were analyzed according to each category. 


\section{The evaluation of the problems resulting from dentures}

According to the questionnaire results of test and control groups, the average answer score was 1.04 and $2.16(\mathrm{p}<0.001)$, respectively. Denture problems in test group were significantly lower than those in control group.

\section{Problems related to mastication capacity}

According to the questionnaire results of test and control groups, the average answer score was 1.11 and $2.01(\mathrm{p}<0.001)$, respectively. It was evaluated in the study that the test group having overdenture had less mastication problems by comparison with the control group with classical dentures.

\section{The evaluation of aesthetical satisfaction}

According to the questionnaire results of test and control groups, the average VAS score was 8.16 and 8.01 ( $\mathrm{p}>0.001$ ), respectively. No statistically significant difference was observed in aesthetical denture satisfaction of both groups. However, when overall satisfaction results were evaluated, the average VAS score for test and control groups were respectively 8.28 and 5.98 . Therefore, overall satisfaction level in test group was significantly higher than the level in control group $(\mathrm{p}<0.001)$ (Table 2).

\section{Discussion}

According to the comparative evaluation of the questionnaires included in the study, the use, mastication comfort and patient satisfaction of supported submaxilla overdenture are better and more acceptable than those of classical complete dentures. According to the answers given by the patients, problems occurring during the use of classical complete dentures can easily be minimized by use of supported overdentures. Aesthetical evaluation results were satisfying and similar in both groups.

In literature, there are many studies comparing the satisfaction level of classical complete dentures and supported overdentures $[16,17]$. In accordance with the findings of our study, many of these studies report that in evaluations such as mastication capacity and patient acceptance, overdentures yield better results than classical complete dentures do. Although some studies report that most patients find overdentures more aesthetic, no significant difference in aesthetical satisfaction was observed in our study.

In literature, many studies report that after two implant supported overdenture are bilaterally placed in mandibular region of edentulous patients, they have better mastication capacity and this affects their psychology and motivation positively and helps them become more self-confident $[18,19]$. Furthermore, these studies also show that patients have better muscle control and mastication capacity. Similarly, in our study, the satisfaction level and mastication capacity of the test group with overdentures was significantly higher. Some studies draw attention to the fact that dentures may not be responsible for mastication capacity in some cases, instead, the mastication capacity might also worsen by age and gender $[18,13,20$ 28]. The fact that no further evaluations depending on age and gender were conducted in our study is one of the limitations of the current study.

\section{References}

1. Feine JS, Carlsson GE, Awad MA, Chehade A, Duncan WJ, Gizani S, et al. The McGill consensus statement on overdentures. Mandibular twoimplant overdentures as first choice standard of care for edentulous patients. Gerodontology. 2002; 19: 3-4.

2. Wolfart S, Braasch $\mathrm{K}$, Brunzel $\mathrm{S}$, Kern M. The central single implant in the edentulous mandible: improvement of function and quality of life. A report of 2 cases. Quintessence Int. 2008; 39: 541-548.

3. Doundoulakis JH, Eckert SE, Lindquist CC, Jeffcoat MK. The implantsupported overdenture as an alternative to the complete mandibular denture. J Am Dent Assoc. 2003; 134: 1455-1458.

4. Feine JS, Carlsson GE, Awad MA, Chehade A, Duncan WJ, Gizani S, et al. The McGill consensus statement on overdentures. Quintessence Int. 2003; 34: 78-79.

5. Mau J, Behneke A, Behneke N, Fritzemeier CU, Gomez-Roman G, d'Hoedt $B$, et al. Randomized multicenter comparison of 2 IMZ and 4 TPS screw implants supporting bar-retained overdentures in 425 edentulous mandibles. Int J Oral Maxillofac Implants. 2003; 18: 835-847.

6. Mericske-Stern R, Zarb GA. Overdentures: an alternative implant methodology for edentulous patients. Int J Prosthodont. 1993; 6: 203-208.

7. Thomason JM, Kelly SA, Bendkowski A, Ellis JS. Two implant retained overdentures $A$ review of the literature supporting the McGill and York consensus statements. J Dent. 2012; 40: 22-34.

8. Thomason JM. The McGill consensus statement on overdentures. Mandibular 2-implant overdentures as first choice standard of care for edentulous patients. Eur J Prosthodont Restor Dent. 2002; 10: 95-96.

9. Thomason JM, Feine J, Exley C, Moynihan P, Müller F, Naert I, et al. Mandibular two implant-supported overdentures as the first choice standard of care for edentulous patients - The York consensus statement. Br Dent J. 2009; 207: 185-186.

10. Pan Y, Lin T, Liang C. Comparison of Patient's Satisfaction with Implantsupported Mandibular Overdentures and Complete Dentures. Biomed J. 2014; 37: 156-162.

11. Cune $M$, van Kampen F, van der Bilt A, Bosman F. Patient satisfaction and preference with magnet, bar-clip, and ball-socket retained mandibular implant overdentures: a cross-over clinicaltrial. Int J Prosthodont. 2005; 18: 99-105.

12. Pace-Balzan A, Butterworth CJ, Dawson LJ, Lowe D, Rogers SN. The further development and validation of the Liverpool Oral Rehabilitation Questionnaire (LORQ) version 3: A cross-sectional survey of patients referred to a dental hospital for removable prostheses replacement. J Prosthet Dent. 2008; 99: 233-242.

13. Boerrigter EM, Geertman ME, Van Oort RP, Bourma J, Raghoebar GM, van Waas MA, et al. Patient satisfaction with implant-retained mandibular overdentures. A comparison with new complete dentures not retained by implants: A multicentre randomized clinical trial. Br J Oral Max Surg. 1995; 33: $282-288$

14. Tallgren A. The continuing reduction of the residual alveolar ridges in complete denture wearers: a mixed-longitudinal study covering 25 years. 1972. J Prosthet Dent. 2003; 89: 427-435.

15. Allen PF, McMillan AS, Walshaw D. A patient-based assessment of implantstabilized and conventional complete dentures. J Prosthet Dent. 2001; 85: 141-147.

16. Doundoulakis JH, Eckert SE, Lindquist CC, Jeffcoat MK. The implantsupported overdenture as an alternative to the complete mandibular denture. J Am Dent Assoc. 2003; 134: 1455-1458.

17. Awad MA. Patient's ratings can be used to measure the satisfaction of different mandibular implant-retained overdentures. J Evid Based Dent Pract. 2005; 5: 154-155.

18. de Grandmont P1, Feine JS, Taché R, Boudrias P, Donohue WB, Tanguay $\mathrm{R}$, et al. Within-subject comparisons of implant-supported mandibular prostheses: psychometric evaluation. J Dent Res. 1994; 73: 1096-1104.

19. Meijer HJ, Raghoebar GM, Van't Hof MA. Comparison of implant-retained mandibular overdentures and conventional complete dentures: a 10-year 
prospective study of clinical aspects and patient satisfaction. Int $\mathrm{J}$ Oral Maxillofac Implants. 2003; 18: 879-885.

20. Pan $\mathrm{YH}$, Lin TM, Liang $\mathrm{CH} 1$. Comparison of patient's satisfaction with implant-supported mandibular overdentures and complete dentures. Biomed J. $2014 ; 37$ : 156-162.

21. Wismeyer D, Van Waas Ma, Vermeeren Ji, Mulder J, Kalk W. Patient satisfaction with implant-supported mandibular overdentures. A comparison of three treatment strategies with ITI-dental implants. Int Oral Maxillofac Surg. 1997; 26: 263-267.

22. John MT, Slade GD, Szentpetery A, Setz JM. Oral health-related quality of life in patients treated with fixed, removable, and complete dentures 1 month and 6 to 12 months after treatment. Int J Prosthodont. 2004; 17: 503-511.

23. Lamb DJ, Ellis B, Kent G. Measurement of changes in complete mandibular denture security using visual analogue scales. Int J Prosthodont. 1994; 7: 30-34.

24. Timmerman R, Stoker GT, Wismeijer D, Oosterveld P, Vermeeren JI, van
Waas MA. An eight-year follow-up to a randomized clinical trial of participant satisfaction with three types of mandibular implant-retained overdentures. J Dent Res. 2004; 83: 630-633.

25. Geertman ME, Slagter AP, van 't Hof MA, van Waas MA, Kalk W. Masticatory performance and chewing experience with implant-retained mandibular overdentures. J Oral Rehabil. 1999; 26: 7-13.

26. Meijer HJ, Raghoebar GM, Van't Hof MA, Geertman ME, Van Oort RP. Implant-retained mandibular overdentures compared with complete dentures; a 5-years' follow-up study of clinical aspects and patient satisfaction. Clin Oral Implants Res. 1999; 10: 238-244.

27. Gjengedal H, Berg E, Boe OE, Trovik TA. Self-reported oral health and denture satisfaction in partially and completely edentulous patients. Int $\mathrm{J}$ Prosthodont. 2011; 24: 9-15.

28. Heydecke G, Boudrias P, Awad MA, De Albuquerque RF, Lund JP, Feine JS. Within-subject comparisons of maxillary fixed and removable implant prostheses: Patient satisfaction and choice of prosthesis. Clin Oral Implants Res. 2003; 14: 125-130
Austin J Dent - Volume 4 Issue 4 - 2017

ISSN : 2381-9189 | www.austinpublishing group.com

Öncï et al. (C) All rights are reserved
Citation: Büyükerkmen EB and Öncü E. Evaluation Quality of Life of Patients Wearing Implant-Supported Overdentures and Conventional Complete Dentures. Austin J Dent. 2017; 4(4): 1077. 